\title{
Rencana Zoning Kawasan Wisata Air di Hutan Kota pada Lahan Bekas Tambang Batubara PT Bukit Asam, (Tbk) Tanjung Enim, Kabupaten Muara Enim
}

\section{Zoning Plan for Water Tourism Areas in Urban Forests on PT Bukit Asam Post Mining Areas, (Tbk) Tanjung Enim, Muara Enim Regency}

\author{
Kiki Andriani ${ }^{\mathrm{a}}$, Nurini ${ }^{\mathrm{b} *}$ \\ ${ }^{a}$ Universitas Diponegoro, Semarang, Indonesia \\ ${ }^{b}$ Universitas Diponegoro, Semarang, Indonesia
}

\begin{abstract}
Abstrak
Kegiatan tambang dapat memberikan degradasi dampak buruk perubuhan lingkungan secara signifikan. Alih fungsi lahan sebagai kawasan penambangan menuntut kegiatan reklamasi pada pasca kegiatan penambangan. Reklamasi merupakan kegiatan yang diwajibkan bagi penguasa pertambangan. Pt Bukit Asam merupakan salah satu perusahaan tambang batubara terbesar di Sumatera Selatan khususnya di Kabupaten Muara Enim berkomitmen untuk melakukan kegiatan reklamasi yang mana akan di implementasikan dalam pembangunan hutan kota H.Kalamudin Djinab, SH, MH pada lahan bekas tambang. Luas lahan yang akan dibangun menjadi hutan kota sebesar 50 Ha yang terdiri beberpa zonasi Metode perancangan dilakukan dari kegiatan survey lapangan, dan observasi untuuk memperoleh data yang dibutuhkan serta dalam melakukan kompilasi data sekunder dan primer. Analisis-analisis dalam penyusunan rencana zoning kawasann hutan kota terdiri dari analisis kebutuhan ruang, analisis aktivitas, analisis karakteristik pengguna, analisis organisasi ruang, analisis tapak dan zoning kawasan. Sehingga diperoleh zoning kawasan hutan kota yang akan dikembangkan menjadi beberapa fungsi yang berbeda di setiap kawasan.
\end{abstract}

Kata kunci: Reklamasi, Hutan Kota, zonasi, lahan bekas tambang

\begin{abstract}
Mine activity can give adverse environmental impacts significantly. Land conversion as mine land demanding reclamation activities on demanding reclamation activities. Reclamation is an activity that is required for mining entrepreneurs. PT Bukit Asam us one of the largest mining company in South Sumatera, district Muara Enim committed to undertake reclamation activities which will be implemented in urban forest development H.Kalamudin Djinab, SH, MH on post land mining. The land area that will be built into the urban forest of 50 hectares consisting some zoning.

The design method is carried out from field survey activities, and observation to obtain the required data as well as in compiling secondary and primary data. The analyzes in preparing zoning plan of urban forest consist of space requirement analysis, activity analysis, user characteristic analysis, space organization analysis, site analysis and zoning area. So that zoning of urban forest area will be developed into several different functions in each area
\end{abstract}

Keyword: Reclamation, Urban Forest, Zoning, Post Mining Area

\section{Pendahuluan}

Penurunan kuantitas dan kualitas dari ruang terbuka akan mempengaruhi nilai kualitas lingkungan perkotaan seperti meningkatnya polusi udara, bencana banjir, serta krisis sosial yang

\footnotetext{
* Nurini, Kiki Andriani

E-mail address: Nur1n1@gmail.com

E-mail address:Kikiandriani.ka@gmail.com
} 
mana kurangnya interaksi antar masyarakat. Ruang Terbuka Hijau sebagai infrastruktur struktur hijau perkotaan adalah bagian dari ruang-ruang terbuka (open space) suatu wilayah perkotaan yang diisi oleh tumbuhan, tanaman dan vegetasi (endemik maupun introduksi) guna mendukung ekologis, sosial, budaya dan arsitektural yang dapat memberikan manfaat ekonomi (kesejahteraan) bagi masyarakat (Lokakarya RTH, 30 November 2005).

Degradasi terhadap penggunaan lahan pada suatu kawasan akan berdampak pada minimnya ruang untuk memenuhi kebutuhan ruang terbuka publik. Khususnya dalam ruang terbuka hijau apabila mengalami penurunan secara kualitas maupun kuantitas akan memberikan dampak buruk bagi lingkungan dan sosial. Salah satu aktifitas yang cukup signifikan dalam memberikan dampak perubahan tutupan lahan adalah kegiatan pertambangan. Pertambangan yang dilakukan dengan sistem terbuka (surface mining) akan mengakibatkan perubahan pola penutupan lahan, baik terjadi di lahan bekas pertambangan, maupun di lahan bekas penimbunan (Republika : Bekas Kawasan Tambang Dirombak Jadi Taman Hutan, 05 Juni 2008).

Kabupaten Muara Enim merupakan salah satu kabupaten dengan komoditas utamanya bergerak dalan tambang batubara dengan perusahaan promotor yakni, PT Bukit Asam (Persero), Tbk. Minimnya ruang terbuka hijau di Kabupaten Muara Enim serta merupakan kota tambang sangat membutuhkan ruang terbuka hijau yang mana dapat di fungsikan sebagai menjaga stabilitas lingkungan serta untuk mendukung aktifitas ekonomi, sosial, dan budaya. Berdasarkan data dari Badan Pusat Statistik Kabupaten Muara Enim, pada tahun 2015 Kabupaten Muara Enim hanya memiliki 27 taman yang mana secara luas keseluruhan hanya 6,38 Ha. Minimnya ruang terbuka hijau di Kabupaten Muara Enim belum memenuhi kebutuhan dalam menjaga ekologis lingkungan.

Beberapa Kejadian sebagai dampak negatif dari kegiatan pertambangan dapat dilihat dari terjadinya ancaman terhadap lingkungan fisik, biologi, sosial, budaya, ekonomi dan warisan nasional, ancaman terhadap ekologi dan pembangunan berkelanjutan (Makurwoto, 1995 : 87). Permasalahan yang kerapkali terjadi pada kegiatan eksplorasi dan eksploitasi sumber daya mineral adalah terjadinya penurunan kualitas lingkungan seperti pencemaran pada tanah, polusi udara, dan hidrologi air (Djauhari Noor, $2006: 3$ ).

Tuntutan untuk penyediaan ruang terbuka hijau untuk menjaga kualitas lingkungan dilakukan dengan adanya kegiatan pasca tambang. Lahan bekas tambang yang tidak dapat di gunakan kembali dilakukan adanya reklamasi dan revegetasi untuk mengembalikan fungsi lahan tersebut dan digunakan menjadi ruang terbuka publik. Secara garis besar keberhasilan revegtasi pada lahan bekas tambang bergantung pada penataan lansekap, kesuburan media tanam, dan penanaman dan perawatan tanaman (Zulkifli, 2014: 102). Salah satu implementasi kegiatan pasca tambang dari Pt Bukit Asam yakni dengan penataan lingkungan agar lahan bekas tambang dapat dimanfaatkan untuk pembangunan TAHURA Enim (PT Bukit Asam, 2013:10). Salah satu zona pada TAHURA terdapat rencana pembangunan Hutan Kota yang akan dikembangkan sebagai salah satu ruang terbuka hijau publik serta sebagai kawasan wisata. Berdasarkan latar belakang dan uraian tersebut adanya kegiatan reklamasi pasca tambang pada lahan tambang batubara mengusahakan adanya kegiatan Pembangunan Taman Hutan Raya (TAHURA) berdasarkan SK Bupati Muara Enim No 889.KPTS/Bapedalda/2005. Sejak 2005. Kegiatan ini akan di realisasikan dengan kegiatan pembangunan Hutan Kota yang terbagi menjadi beberapa zona yang digunakan untuk memenuhi kebutuhan ruang terbuka hijau dan menjaga kualitas lingkungan (Ekologis).

Sebagai promotor utama perusahaan tambang, PTBA berkomitmen untuk mengembangkan areal yang sudah selesai ditambang untuk dikelola secara bertanggung jawab, melalui kegiatan reklamasi, revegetasi dan pasca tambang. PT Bukit Asam sebagai perusahaan tambang di Kabupaten Muara Enim telah mengupayakan dalam mengembalikan perbaikan lingkungan salah satunya dalam pembangunan hutan kota untuk mengembalikan fungsi lahan serta memperbaiki ekologis lingkungan pasca kegiatan tambang ( Dinas Lingkungan Hidup Kabupaten Muara Enim, 2010:III-5). Sehingga dari beberapa latar belakang tersebut akan menjawab akan "Bagaimana rencana zoning kawasan pada Hutan Kota H.Kalamudin Djinab, SH, MH sebagai kegiatan reklamasi lahan pasca tambang yang berkelanjutan”.

Secara administrasi lokasi perancangan berada di Desa Karang raja, Kecamatan Muara Enim, Kabupaten Muara Enim. lokasi penelitian merupakan lahan bekas tambang penimbunan milik PT Bukit Asam (Persero), Tbk. Lahan bekas tambang yang akan digunakan untuk hutan kota berada di lokasi spreader di IUP Tambang Air Laya. Serta berbatasan langsung dengan 
wilayah kota Muara Enim. Luas lahan untuk rencana pembangunan hutan kota sebesar $50 \mathrm{Ha}$ berdasarkan Keputusan Bupati Muara Enim Nomor 550/KPTS/HUT/2011.

Secara administrasi, lokasi makro batas lokasi hutan kota tersebut juga terletak di sepanjang perbatasan antara kawasan perkotaan dan kawasan pertambangan batubara PT Bukit Asam. Sehingga lokasi yang strategis tersebut dapat hutan kota yakni :

Sebelah Utara $\quad$ : TPA dan Lahan masyarakat

Sebelah Barat $\quad$ : Kawasan Pertambangan PT Bukit Asam (Persero), Tbk

Sebelah Selatan : Kawasan Pertambangan PT Bukit Asam (Persero), Tbk

Sebelah Timur : : Lahan masyarakat
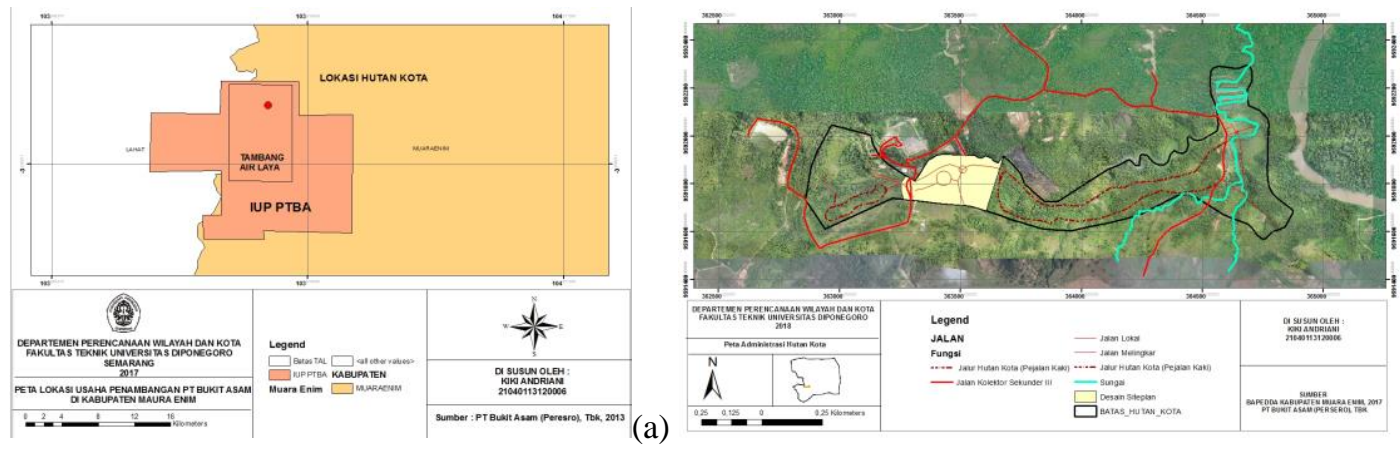

(b)

Gambar 1. (a) Peta Lokasi Hutan Kota di IUP Tambang Air Laya ; (b) Peta Batas Lokasi Penelitian terhadap Batas Makro (Hutan Kota) (PT Bukit Asam (Persero), Tbk, 2014)

Pada perencanaan hutan kota yang telah disusun bersama pihak PT Bukit Asam dan Dinas Lingkungan Hidup Kabupaten Muara Enim terbagi menjadi beberapa zonasi. Zonasi tersebut terbagi menjadi kawasan kawasan pembibitan, water park, hutan, dan bumi perkemahan.

\section{Metode Penelitian Kuantitatif}

Teknik penetuan sampling data menggunakan teknik sampling Probality Sampling yang mana memberikan peluang yang sama bagi setiap unsur populasi untuk dipilih menjadi anggota sampel. Jenis Probality Sampling yang digunakan adalah Proportionate Stratified Random Sampling yang mana populasi mempunyai susunan bertingkat atau berlapis serta anggota populasi yang tidak homogen (Sugiyono, 2001 ; 58). Responden penelitan merupakan masyarakat kabupaten Muara Enim berdasarkan tingkatan golongan umur. Metode penelitian menggunakan pendekatan kuantitatif atau deduktif. Adapun tahapan dalam penelitian yakni:

1. Penentuan Isu Utama ditinjau dari permasalahan yang ada di Kabupaten Muara Enim khususnya dari aspek kegiatan penambangan yang mana sebagai kota tambang.

2. Penetuan wilayah studi untuk mengetahui fokus kajian yang dibahas dalam studi perancangan dan pembangunan. Penentuan wilayah studi dilihat dari identifikasi potensi dan masalah. Penentun wilayah studi melihat potensi yang akan dikembangkan menjadi kawasan baru.

3. Survey dan Pengelolaan data dilakukan untuk mendukung dalam kebutuhan data yang diperlukan untuk menganalisis dan merancang konsep. Survey dilakukan melalui observasi lapangan, wawancara, kuesioner, dan telaah dokumen terkait. Dari survey lapangan tersebut di dapatkan data-data mendukung dalam analisis dan rancangan kawasan. pengelolaan data hasil suvey yang mana kan di sajikan dalam bentuk diagram, deskriptif, serta persebaran frekuensi. Dari pengelolaan data hasil survey lapangan dapat digunakan untuk analisis dalam merancang kawasan hutan kota.

Analisis digunakan dalam proses penyusunan rancangan kawasan. Analisis ini terdapat analisis karakteristik pengguna, analisis aktifitas, analisis kebutuhan ruang, analisis organisasi ruang, analisis tapak dan zoning kawasan. 


\section{Kajian Literatur Perancangan Zoning Hutan Kota Pada Lahan Bekas Tambang}

\subsection{Ruang Terbuka Hijau}

Ruang terbuka hijau adalah suatu lahan atau kawasan yang mengandung unsur dan struktur alami yang dapat menjalankan proses-proses ekologis, seperti pengendali pencemaran udara, ameliorasi iklim, pengendali tata air, dan sebagaiannya (Joga \& Ismaun, 2011:92). RTH merupakan bagian dari ruang terbuka yang mana di definisikan sebagai ruang yang mengandung unsur dan struktur alami. Klasifikasi RTH terdiri atas RTH lindung (wilderness areas, protected areas, natural pack areas) dan RTH binaan (Urban park area, recreational areas, urban development open spaces) (Joga \& Ismaun, 2011:93).

\subsection{Hutan Kota}

Hutan kota merupakan bagian dari bentuk ruang terbuka hijau. Menurut Fakuara (1987) dalam Dahlan (1992) mengemukakan bahwa Hutan Kota adalah tumbuhan atau vegetasi berkayu di wilayah perkotaan yang memberikan manfaat lingkungan yang sebesar-besarnya dalam kegunaan proteksi, estetika, rekreasi, dan kegunaan khusus lainnya. Dahlan (1992: 29) membagi pendekatan pembangunan hutan kota menjadi dua pendekatan. Pendekatan pertama, pembangunan hutan kota dibangun pada lokasi-lokasi tertentu dengan penentuan luasanya berdasarkan persentase luasan hutan kota, perhitungan perkapita jumlah penduduknya, serta berdasarkan isu utama yang ada. Sedangkan untuk pendekatan kedua,semua areal yang ada disuatu kota pada dasarnya merupakan areal untuk hutan kota.

Hutan kota memiliki beberapa peranan berdasarkan peruntukan aktivitas kota seperti hutan kota konservasi, hutan kota industri, hutan kota wilayah permukiman, hutan kota wisata dan hutan kota tangkar satwa. Merujuk dari Peraturan Mentri Kehutanan Republik indonesia Nomor P.71/Menhut-II/2009 tentang Pedoman penyelengaraan Hutan Kota juga memaparkan terkait bentuk hutan kota yakni, jalur hijau, taman kota, kebun, kebun raya, hutan raya, kebun binatang, hutan raya, dan hutan lindung.

\subsection{Penentuan Vegetasi}

Vegetasi atau komunitas adalah salah satu komponen biotik yang menempati habitat tertentu seperti hutan, padang ilalang, semak belukar dan lain-lain (Arrijani, Setiadi, Guhardja, Qayim, 2006:147). Menurut Chiara \& Koppelman (1978:3) pertimbangan pemelihan vegetasi berdasarkan Kepadatan tajuk, Ketinggian permukaan atas, Ketinggian permukaan bawah, ketinggian kawasan dan suhu minimum rata-rata pada kawasan. pemilihin berdasarkan tajuk dapat ditinjau dari bentuk tajuk dan kepadatan tajuk (Mahendra, 2009:92).

\subsection{Rancangan Tapak}

Menurut Lynch \& Hack (1983) Site Palnning atau perancangan tapak adalah suatu karya seni yang menyusun struktur dalam lahan dan membentuk ruang antaranya, seni yang berkaitan dengan arsitektur, teknik, arsitektur lansekap, dan perancanaan kota (Lynch \& Hack, 1983:1). Menurut Lynch dan Hack (1983:29) menyebutkan pada tahap perancangan tapak terdapat memprogram dan analisis tapak serta pengguna. Menurut (Rubenstein, 1996:12) membagi tahapan analisis tapak berpengaruh pada faktor alam yakni, lingkungan, totpgrafi, kebisingan, aksesibilitas, lintasan matahari dan angin, drainase, view, dan vegetasi. Analisis perancangan tapak dan lingkungannya terdiri dari kondisi alam,budaya, dan faktor estetis yang mempengaruhinya. Fitur tersebut mempengaruhi pemilihan lokasi dan memberikan petunjuk sifat maupun karakter tapak yang akan membantu menetapkan pedoman untuk pengembangan selanjutnya (Rubenstein, 1996:12). Selain berdasarkan faktor alam dan faktor budaya, analisis tapak juga dipengaruhi oleh faktor estetis yang terdiri fitur alam dan pola spasial. Karakter dari tapak dibedakan dari elemen fitur alam dan pola spasial (Rubenstein, 1996:61). Sehingga hasil dari analisis tapak tersebut menghasilkan perancanaan zonasi kawasan. analisis tapak pada penelitian terdiri beberapa analisis fisik terkait seperti konstelasi wilayah, topografi, aksesibilitas, view, veegtasi, lintasan matahari dan angin, kebisingan, lingkungan, serta hasil akhir berupa overlay dari semua analisis tapak berupa zoning kawasan hutan kota. 
Perancangan tapak tidak hanya berdasarkan pada penggunaan lahan dan sirkulasi, perancangan visual faktor kontekstual serta elemen alam akan tetapi perencanaan juga dilihat dari bentuk organisasi ruang. Bentuk organisasi ruang dengan bangunan, alam, bebatuan, air, dan bahan tanaman harus terstruktur.

\section{Hasil Pembahasan}

Perancangan zoning hutan kota pada lahan bekas tambang batubara mengacu pada beberapa analisis yakni analisis pengguna, aktivitas, dan analisis tapak . Masing-masing analisis menghasilkan keluaran yang akan berpengaruh pada perancangan zoning kawasan hutan kota yang mana komponen-komponen tersebut akan dapat dilakukan analisis perancangan selanjutnya.

\subsection{Analisis Pengguna, Aktivitas, dan Kebutuhan ruang}

Analisis ini digunakan untuk kajian terhadap kelompok aktivitas yang ada di hutan koa dan juga untuk mengetahui karakteristik dari kebutuhan ruang yang direncakan dalam menunjang perancangan ruang fisik kawasan. Zoning pada hutan kota akan diarahkan menjadi kawasan wisata serta dapat dimanfaatkan menjaga keseimbangan ekologis lingkung pasca kegiatan tambang. Analisis ini terdiri dari analisis pengguna dan karakteristik aktivitas, analisis carrying capacity, analisis kebutuhan ruang, analisis hubungan antar ruang dan analisis organisasi ruang.

Secara keseluruhan luas lahan rencana hutan kota sebesar $50 \mathrm{Ha}$ atau $500.000 \mathrm{~m}^{2}$. Jumlah tersebut sebesar $200.000 \mathrm{~m}^{2}$ merupakan kawasan terbangun dan $300.000 \mathrm{~m}^{2}$ merupakan kawasan non terbangun. Luasan tersebut berdasarkan kesepakatan bersama antara PT Bukit asam dan Dinas Lingkungan Hidup Kabupaten Muara Enim. Maka luasan sirkulasi sebesar 30\% dari luas terbangun yaitu $3 \mathrm{Ha}$ atau $60.000 \mathrm{~m}^{2}$ yang dibangun pada lahan non terbangun. Jadi secara keseluruhan luas kawasan terbangun sebesar $140.000 \mathrm{~m}^{2}$ dan $60.000 \mathrm{~m}^{2}$ diperuntukkan sirkulasi. Kapasitas maksimum diasumsikan untuk membagikan antara lahan hutan kota yang tersedia dengan kebutuhan perorangan. Peraturan Menteri Pekerjaan Umum Nomor 05/PRT/M/2008 tentang Pedoman Penyediaan dan Pemanfaatan Ruang Terbuka Hijau di Kawasan Perkotaan, kapasitas maksimum pelaynan untuk Hutan kota dapat ialah 480.000 jiwa.

\subsection{Analisis Tapak dan Zoning Kawasan}

Penggunaan analisis tapak pada perancangan waterpark pada hutan kota yang akan difungsikan sebagai lokasi wisata dimaksudkan untuk menentukan dasar perencanaan tapak. Pada analisis dilakukan dengan berbasis menerapkan ruang terbuka hijau publik sebagai lokasi wisata yang serta dapat meningkatkan kualitas lingkungan. Perencanaan tapak enggunakan beberapa analisis yaitu, konstelasi wilayah, topografi, aksesibilitas, view, vegetasi, lintasan matahari dan angin, kebisingan, dan lingkungan. Sehingga dari semua analsis akan menghasilkan zonasi fungsi peruntukan lahan.

\section{A. Analisis Topografi}

Nilai eleveasi pada kawasan dimulai dari 30 meter sampai 95 sehingga terdapat kawasan yang bersifat curam maupun landai. Pada kawasan berwarna orange merupakan kawasan dengan kontur renggang atau bersifat landai. Sedangkan untuk kawasan berwarna hijau bersifat rapat atau curam. Sehingga pada kawasan berwarna hijau akan dikembangkan sebagai kawasan non terbangun sedangkan berwarna orange dikembangkan sebagai kawasan terbangun. 


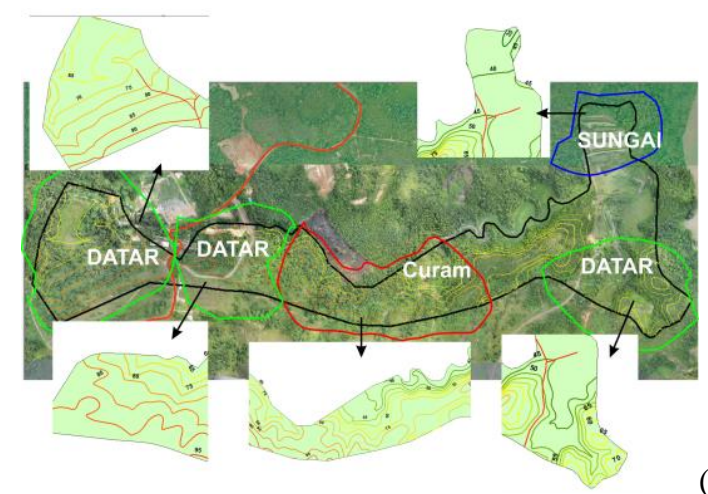

(a)

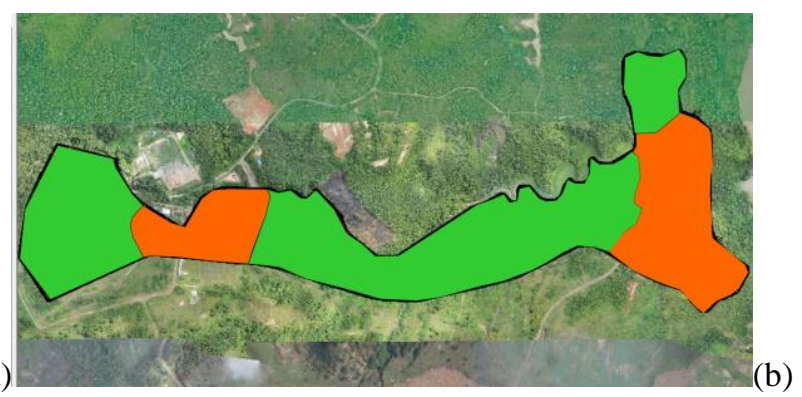

Gambar 2. (a) Gambar Kondisi Topografi pada Kawasan (PT Bukit Asam (Persero), Tbk, 2014), (b) Gambar Rencana Topografi pada Kawasan (Analisis Penulis,2017)

\section{B. Analisis Aksesibilitas}

Secara kondisi eksisting aksesibilitas tinggi berada di kawasan yang tersedia jalur masuk menuju kawasan. sehingga untuk rencana aksesibilitas menadi zona publik dan zona privat pada kawasan. untuk zona publik berupa kawasan berwarna kuning yang akan dikembangkan menjadi kawasan terbangun serta beberapa ruang terbuka hijau yang akan digunakan pengguna sebagai ruang berinteraksi.
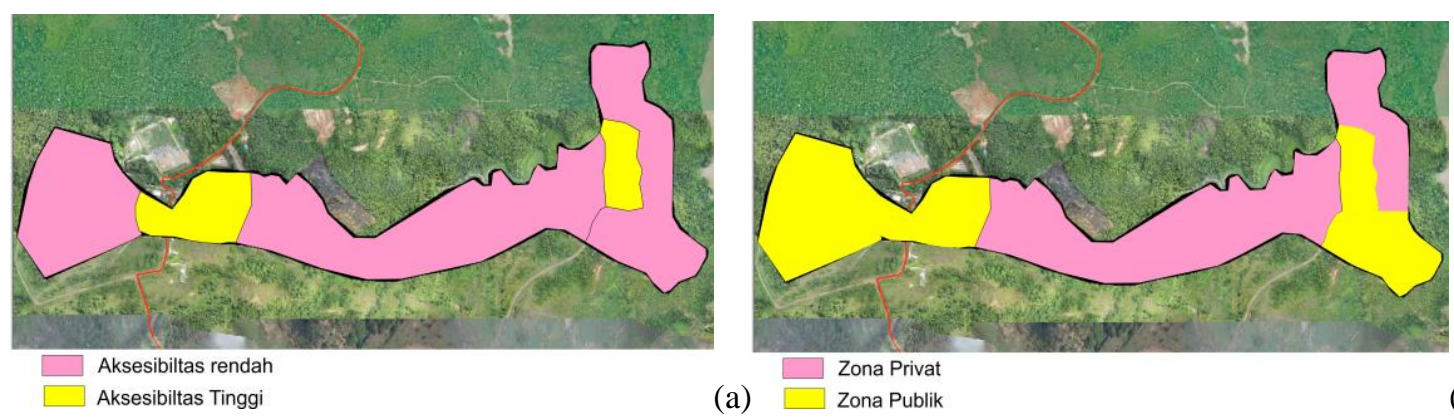

Gambar 3. (a) Gambar Kondisi Aksesibilitas yang tersedia (PT Bukit Asam (Persero), Tbk, 2014), (b) Gambar Rencana Tingkat aksesibilitas (Analisis Penulis, 2017)

\section{Analisis View}

Analisis view pada kawasan terdapat analisis view from site terdapat pada jalan masuk menuju hutan kota di jalan kolektor sekunder. Selain itu terdapat view to site berupa aliran sungai di sisi barat kawasan. Pada rencana view pada kawasan akan dibuat menjadi view from site berupa gerbang pintu masuk kawasan serta pemandangan berupa jalanan dengan vegetasi yang rindang. Sedangkan untuk Pemandangan yang akan dapat dilihat ke dalam hutan kota adalah nama kawasan hutan kota di main entrance sebagai penanda hutan kota. Nama hutan kota pada main entrance adalah "Hutan Kota H.Kalamudin Djinab SH, MH" di pintu tama bagian bara hutan kota dan "H.Kalamudin Djinab SH, MH Camp Ground" di pintu masuk bumi perkemahan bagian timur hutan kota. Selain itu juga berupa skyline dari bangunan dan vegetasi di hutan kota. Pada waterpark, untuk skyline tertinggi merupakan pohon-pohon di sekitar waterpark serta wahana permainan air. 

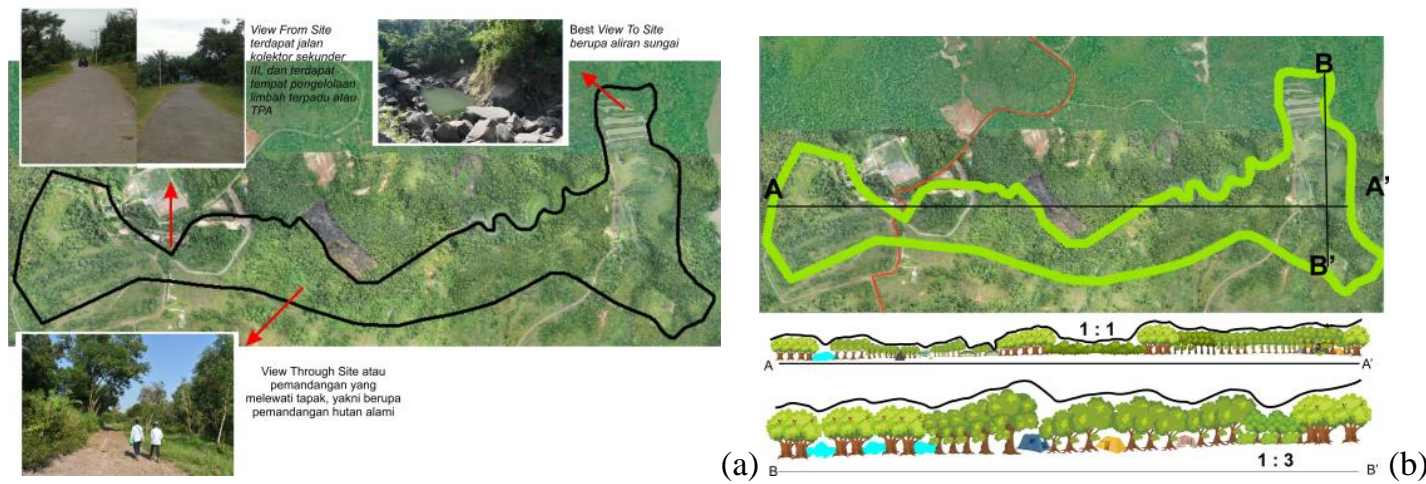

Gambar 4. (a) Gambar Kondisi Vegetasi pada Kawasan (PT Bukit Asam (Persero), Tbk, 2014), (b) Gambar Rencana view pada Kawasan (Analisis Penulis, 2017)

\section{Analisis Vegetasi}

Vegetasi reklamasi pada hutan kota merupakan famili leguminocae atau kacangkacangan. Jenis-jenis vegetasi yanga ada berupa Kormis (Acacia auriculaeformis), Sengon (Albizia falcata), tongke hutan (Acacia mangium), Angsana (Pterocarpus indicus), Hujan Emas seperti flamboyan (Cassia multijuga), dan Petai Cina (leucauna glauca).Jenis tumbuhan untuk vegetasi pioner( tanaman asli) yakni rumput gegenjuran (Phaspalum sp), Waru (Hibiscus tiliaceus), Senggani (melastoma) dan Putri malu (Mimosa invisa). Pada rencana vegetasi yanga akan diterapkan pada kawasan terdiri berbagai jenis vegetasi. Vegetasi Pada barrier kawasan difungsikan sebagai penanda kawasan, peredam kebisingan menyerap polutan dari aktivitas di luar kawasan. Vegetasi tersebut berupa pohon Mahoni sebagai barrier pada sisi utara dan selatan kawasan serta dengan jarak tanam 8 meter. Selain pohon Mahoni, barrier kawasan zona wisata dengan zona lainnya menggunakan vegetasi berupa pohon Sengon. Vegetasi pada jalan kolektor sekunder III dan jalan lokal pada kawasan perancangan menggunakan pohon Akasia untuk jalan raya sedangkan untuk jalan lingkungan pada plaza menggunakan pohon Pinus merkusi, dan cemara kipas. Vegetasi pada kawasan hutan terdapat pohon Jati, Kenanga, Cemara, Ketapang, Mahoni, Angsana dengan bentok pola berstrata banyak. Sedangkan vegetasi pada aktivitas utama berupa pohon Palem, Pohon Mahoni, Pohon Pinang, Pohon Kiara Payung, dan Pohon Ketapang. Vegetasi pada aktivitas penunjang seperti penginapan menggunakan perpaduan antara vegetasi Angsana, Kenanga, bogenvil, Lantana merah, Jati, Kiara Payung, kembang sepatu dan Mangga.
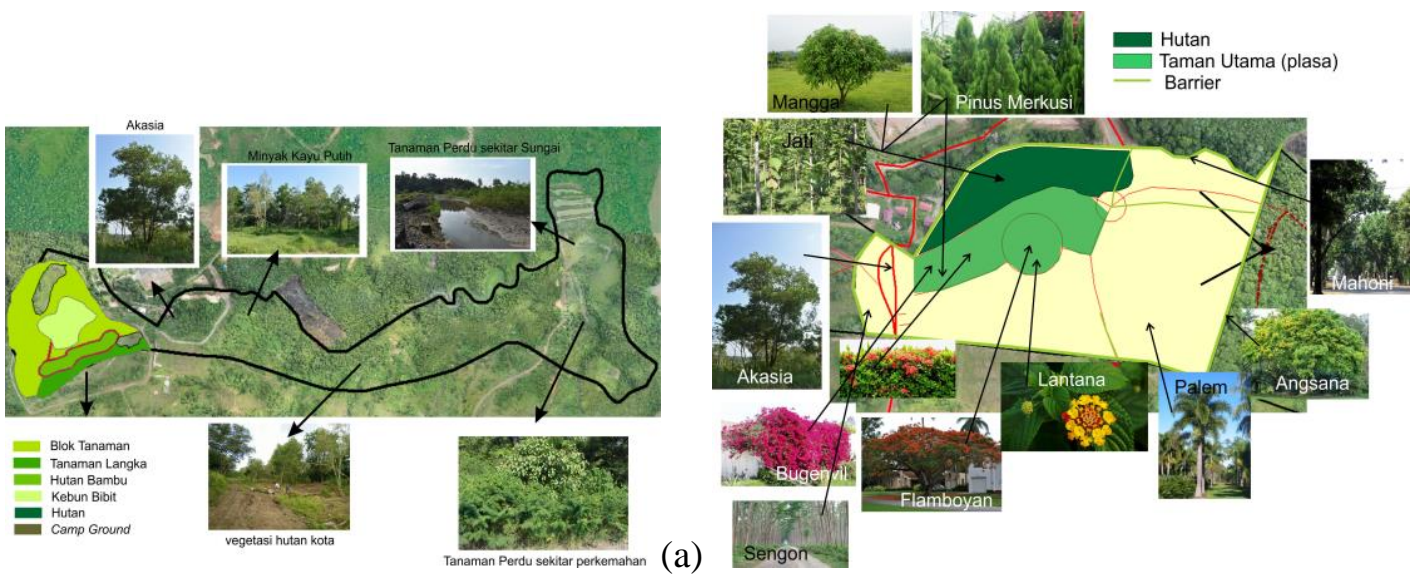

(b)

Gambar 5. (a) Gambar Kondisi Vegetasi pada Kawasan(PT Bukit Asam (Persero), Tbk, 2014), (b) Gambar Rencana view pada Kawasan (Analisis Penulis, 2017) 
E. Analisis Lintasan Matahari dan Angin
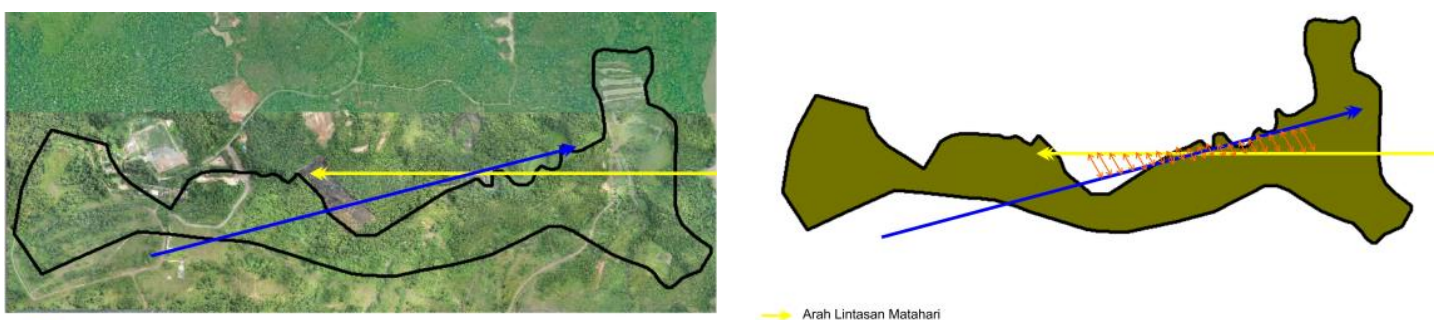

Gambar 6. (a) Gambar Arah matahari dan angin (PT Bukit Asam (Persero), Tbk, 2014), (b) Gambar Rencana arah bangunan (Analisis Penulis, 2017)

Arah matahari bergerak dari Timur (T) ke Barat (B) sedangkan Arah angin pada hutan kota bergerak dari arah dataran tinggi bergerak menuju dataran rendah atau dari Barat Daya (BD) menuju Timur laut (TL). Di antara kedua arah angin dan matahari, arah bangunan menghadap ke arah Barat Laut atau Tenggara. Hal ini ditujukan agar bangunan-bangunan tersebut mendapatkan pencahayaan matahari yang cukup di pagi, siang, maupun sore hari untuk mengurangi kelembaban serta mendapatkan sirkulasi udara yang lebih lancar. Akan tetapi tidak semua bangunan mengikuti arah tersebut, mayoritas bangunan menghadap ke utara maupun selatan.

\section{F. Analisis Kebisingan}

Secara eksisting tingkat kebisingan kawasan berdasarkan ketersediaan aksesibiltas serta sisi selatan yang berbatasan dengan kawasan pertambangan lainnya. Sehingga berdasarkan kondisi tersebut juga dibagi menjadi kawasan publik dan privat yang mana zona publik dapat diakses dengan masyarakat umum atau pengguna. Sedangkan untuk zona privat merupakan kawasan yang difungsikan sebagai ruang terbuka hijau pasif dan sungai yang difungsikan sebagai keseimbangan lingkungan.

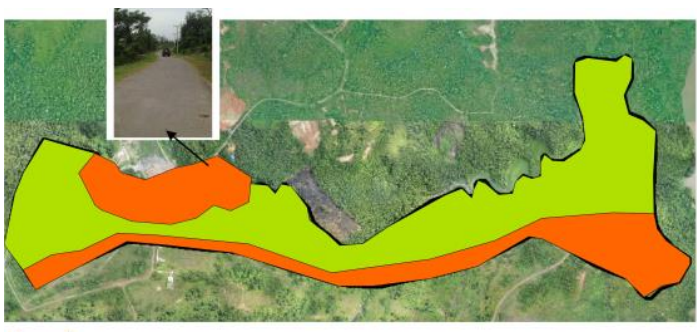

Kebisingan Tinggi

Kebisingan Rendah

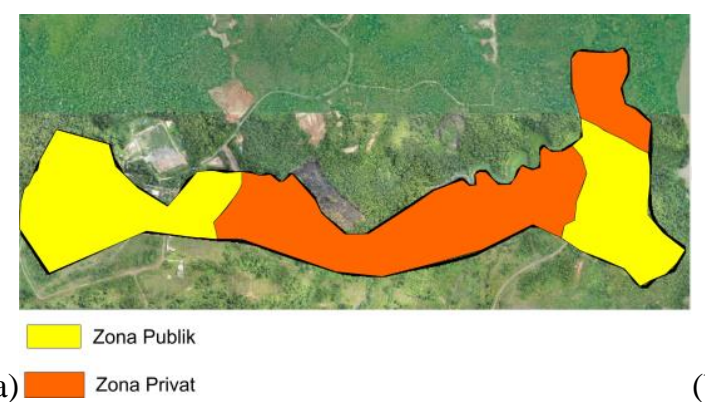

(b)

Gambar 7. (a) Gambar kondisi tingkat kebisingan(PT Bukit Asam (Persero), Tbk, 2014), (b) Gambar Rencana arahan pembagian zona (Analisis Penulis, 2017)

\section{G. Analisis Lingkungan}

Pada lokasi perancangan hutan kota di lalui oleh jalan kolektor sekunder serta berbatasan dengan TPA Muara Enim. Analisis lingkungan tersebut melihat sarana yang berada di luar kawasan perancangan, yang nantinya akan tercipta zonasi bagi kawasan yang akan di rancang. Sehingga terdapat beberapa zona aktivitas, yakbi zona aktivitas utama, zona aktivitas penunjang, zona barrier. 

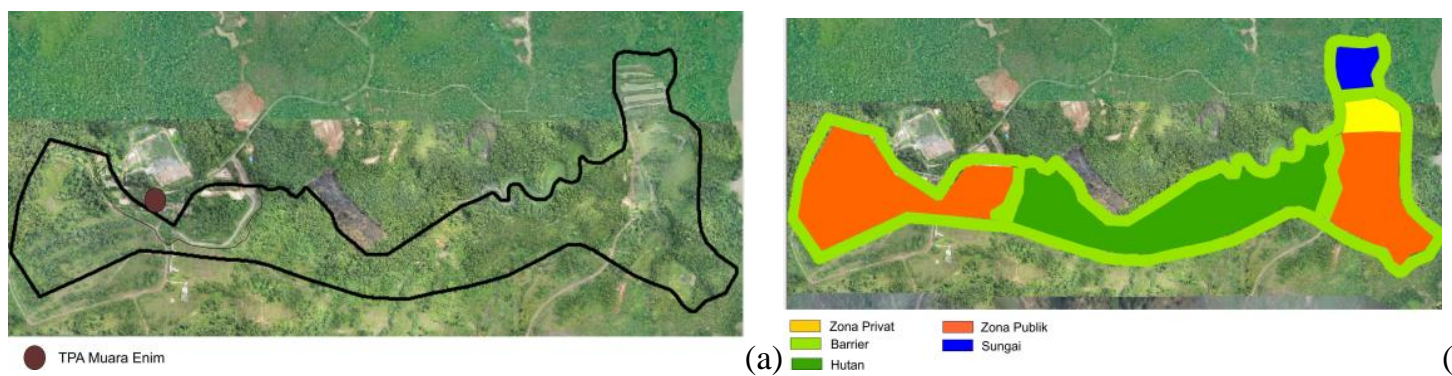

(b)

Gambar 8. (a) Gambar Kondisi Lingkungan sekitar pada Kawasan (PT Bukit Asam (Persero), Tbk, 2014), (b) Gambar Rencana zonasi (Analisis Penulis,2017)

\section{H. Zoning Kawasan}

Analisis Zoning kawasan hutan kota merupakan hasil overlay dari analisis lingkungan, topografi, kebisingan, dan aksesibiltas. Hasil dari analisis tersebut digunakan untuk penentuan zoning hutan kota. Hal ini dilakukan karna dapat memberikan rasa aman dan nyaman bagi pengunjung hutan kota. Berikut penjabaran zoning kawasan pada hutan kota

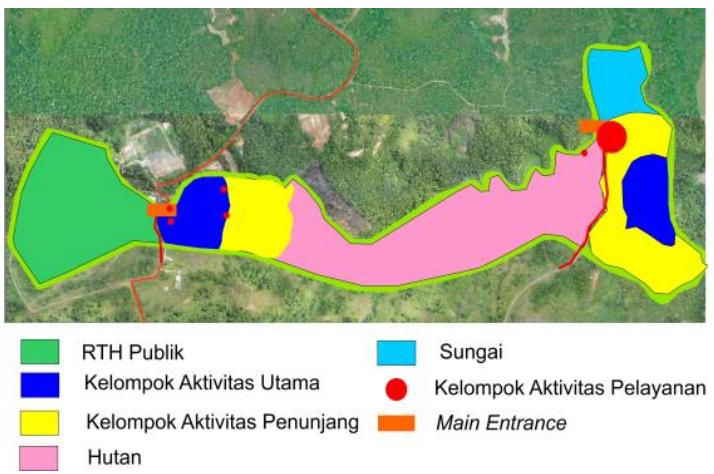

Gambar 9. Zoning Kawasan perancangan (Analisis Penulis, 2017)

Berdasarkan gambar diatas, zonasi kawasan terbagi menjadi aktivitas utama sebagai ruang untuk kegiatan utama di kawasan tersebut seperti perkemahan dan waterpark. Sedangkan untuk aktivitas penunjang sebagai ruang untuk bangunan yang akan emnunjang kegiatan utama. Serta aktivitas pelayanan sebagai ruang untuk memberikan pelayanan terhadap aktivitas utama dan penunjang ataupun seluruh pengguna kawasan. selain itu terdapat barrier kawasan sebagai pembatas maupun peredam kebisingan pada kawasan. terdapat kawasan hutan dengan fungsi yang tetap dipertahankan.

\section{Kesimpulan dan Rekomendasi}

\subsection{Kesimpulan}

Secara keseluruhan dari analisis tapak merupakan pembagian zonasi berdasarkan kondisi fisik, non fisik, maupun kondisi lingkungan sekitar. Sehingga terbagi menjadi beberapa zonasi seperti aktivitas utama sebagai ruang untuk kegiatan utama, aktivitas penunjang, pelayanan, hutan, barrier, dan main entrance. Pebagian zonasi awal tersebut dapat mengembangkan kawasan baik secara estetika dan mengembangkan rancang masing-masing kawasan. sehingga dari zonasi tersebut sebagai tahap awal dalam peruntukan penggunaan lahan.

\subsection{Rekomendasi}

Perancangan hutan kota secara keseluruhan sebesar 50 Ha dari hutan kota. Akan tetapi untuk desain rancangan kawasan masih terbatas zonasi tapak. Perlu adanya pengembangan desain rancangan kawasan dari tiga aktivitas lainnya akan semakin memperluas serta memberikan ide kreatif dalam proses pengembangan perancanaan hutan kota serta pengetahuan di bidang perencanaan wilayah dan kota. 


\section{Referensi}

Anonim. (2008, Juni 05). Bekas Kawasan Tambang Dirombak Jadi Taman Hutan. Diambil kembali dari http://dev.republika.co.id/: http://dev.republika.co.id/berita/koran/448594

Anonim. (2011). Laporan Monitoring dan Evaluasi Tahura Enim. Tanjung Enim: PT Bukit Asam.

ARRIJANI, D. S. (2006). Analisis Vegetasi Hulu DAS Cianjur Taman Nasional Gunung GedePangrango. Biodiversitas, 147-153.

BPS Muara Enim. (2015). Statistik Daerah Kabupaten Muara Enim. Muara Enim: BPS Muara Enim.

Chiara, J. D., \& Koppelman, L. E. (1978). Site Planning Standards. Newyork: McGraw-Hill, Inc.

Dahlan, E. N. (1992). Hutan Kota Untuk Pengelolaan dan Peningkatan Kualitas Lingkungan Hidup. Jakarta: Asosiasi Pengusaha Hutan Indonesia (APHI).

Dinas Lingkungan Hidup Kabupaten Muara Enim. (2010). Laporan Status Lingkungan Hidup Daerah (SLHD) Kabupaten Muara Enim Tahun 2010. Muara Enim: Dinas Lingkungan Hidup Kabupaten Muara Enim.

Joga, N., \& Ismaun, I. (2011). RTH 30\% ! Resolusi (Kota) Hijau. Jakarta: PT Gramedia Pustaka Utama.

Lynch, K., \& Hack, G. (1983). Site Planning. Cambridge: The MIT Press.

Noor, D. (2011). Geologi Perencanaan. Yogyakarta: Graha Ilmu.

Pt Bukit Asam (Persero), Tbk. (2017). Lingkungan. Diambil kembali dari http://www.ptba.co.id: http://www.ptba.co.id/id/lingkungan\#post-mining

Republik Indonesia. (2009). UNDHNG-UNDANG REPUBLIK INDONESIA NOMOR 4 TAHUN 2009 TENTANG PERTAMBANGAN MINERAL DAN BATUBARA. Jakarta: LEMBARAN NEGARA REPUBLIK INDONESIA TAHUN 2009 NOMOR 4.

Unit Pertambangan Tanjung Enim Pt Bukit Asam (Persero), Tbk. (2014). Dokumen Ringkasan Kinerja Pengelolaan Lingkungan. Tanjung Enim: Pt. Bukit Asam (Persero), Tbk.

Zulkifli, A. (2014). Pengelolaan Tambang Berkelanjutan. Yogyakarta: Graha Ilmu. 